23 Hui W-M, Lam A-K, Ho J, et al. Chronic antral gastritis in duodenal ulcer. Natural history and treatment with prostaglandin $\mathrm{E}$ 1. (iustroenterologv 1986;91:1095-101.

24 Cheli R, Giacosa A. Duodenal ulcer and chronic gastritis. Endoscopy 1986;18:125-6.

5 . Moore SC, Malgelada J-R, Shorter RG, Zinmeister AR. Interrelationship among gastric mucosal morphology, secretion, and motility in peptic ulcer disease. Dig Dis $S_{c i} 1986 ; 31: 673-83$.

26 Joffe SN, Lee FD, Blumgart LH. Duodenitis. Clinics in Gastroenterology 1978;7:635-50.

27 Meikle DD, Taylor KB. Truelove SC, Whitehead R. Gastritis duodenitis, and circulating levels of gastrin in duodenal ulcer before and after vagotomy. Gut 1976;17:719-28.

28 Hasan $M$. Sircus W, Ferguson $A$. Duodenal mucosal architecture in non-specific and ulcer associated duodenitis. (iut 1981;22:637-41

29 Cotton PB, Price AB, Tighe JR, Beales JSM. Preliminary evaluation of "duodenitis" by endoscopy and biopsy. BMF 1973;iii:430-3.

30) Fullman H, Deventer (iV, Schneidman D, Walsh J, Elashoff J, Weinstein W. "Healed" duodenal ulcers are histologically ill. Gastroenterology 1985;88:1390.

31 Moshall MG, Gregory MA, Pillay C, Pitaels JM. Does the duodenal cell ever return to normal? A comparison between treatment with cimetidine and DeNol. Scand f Gastroenterol 1979;14 (suppl $56): 48-51$

32 Paoluzi P, Pallone F, Zaccardelli E, Ripoli F, Marcheggiano A, Carratu R. Outcome of ulcerassociated duodenitis after short-term medical treatment. Dig Dis Sci 1985;30:624-9.

33 Johnson BJ, Reed I, Ali MH. Campylobacter-like organisms in duodenal and antral endoscopic biopsies: relationship to inflammation. Gut 1984:25:1132-7.

34 Steer HW. Surface morphology of the gastroduodenal mucosa in duodenal ulceration. (iut 1984;25:1203-10

35 Wyatt JI, Rathbone BJ, Dixon MF, et al. Campylobacter pyloridis and acid-induced gastric metaplasia in the pathogenesis of duodenitis. F Clin Pathol 1987;40:841-8.

36 Bode G, Malfertheiner P, Ditschuneit H. Pathogenetic implications of ultrastructural findings in Campylobacter pylori related gastroduodenal disease. Scand f Gastroenterol 1988;23(suppl $142): 25-35$.

37 Caselli M, Bovolenta MR. Aleotti A, et al. Epithelial morphology of duodenal bulb and campylobacter-like organisms. I Submicrosc Cytol Pathol 1988;20:237-42.

38 Florey HW, Harding HE. The healing of artificial defects of the duodenal mucosa. Foumal of Pathology and Bacteriology 1935;40:211-8.

39 Florey HW, Jennings MA, Jennings DA, O'Connor RC. The reaction of the intestine of the pig to gastric juice. Fournal of Pathology and Bacteriologv 1939;49:105-23.

40 Rhodes J. Experimental production of gastric epithelium in the duodenum. (iut 1964;5:454-8.

11 James AJ. (iastric epithelium in the duodenum. ( iut 1964;5:285-94

42 Patrick WJA, Denham D, Forrest APM. Mucus change in the human duodenum: a light and elecron microscopic study and correlation with disease and gastric acid secretion. (iuc $1974: 25: 767-76$

43 Sipponen P, Deppala K, Aarynen M, Kettunen P. Chronic gastritis and gastroduodenal ulcer: a case-control study on risk of coexisting duodenal or gastric ulcer in patients with gastritis. (ith 1989;30:922-9.

44 Levi S, Beardshall K, Haddad G, Playford R, Ghosh P, Calam J. Campylobacter pylori and duodenal ulcers: the gastrin link. Lancet 1989;i:1167-8.

45 McColl KEL, Fullarton GM, Nujumi AME, Macdonald AM, Brown IL, Hilditch TE. Lowered gastrin and gastric acidity after eradication of Campylobacter pvlori in duodenal ulcer. Lancet 1989;ii:499-500.

46 Coghlan J( , Tobin A, O'Morain C. Campylobacter pylori and ulcer treatment. In: Rathbone BJ, Heatley RV, eds. Campylobacter pylori and gastroduodenal disease. Oxford: Blackwell Scientific, 1989:232-45.

47 Coghlan JG, Gilligan D, Humphries H, et al. Campylobacter pylori and recurrence of duodenal ulcers - a 12 months follow-un studv. Lancet 1987;ii:1109-11.

48 Marshall BJ, Goodwin CS, Warren JR, et al. Prospective double-blind trial of duodenal ulcer relapse after eradication of Campylobacter pylori. Lancet 1988;ii:1437-41.

49 Smith AC, Price AB, Borriello P, Levi AJ. A comparison of ranitidine and tripotassium dicitratobismuthate (TDB) in relapse rates of duodenal ulcer. The role of Campylobacter pylori (C.p.). (Fastroenterology 1988;94:A431

50 Rauws EAJ, Tytgat GNJ. Eradication of H pylori cures duodenal ulcer. Lancet 1990;335:1233-5.

51 George L, Hyland L, Morgan A, et al. Smoking does not contribute to duodenal ulcer relapse after eradication. Gastroenterologv 1990;98:A48.

52 Patchett S, O'Riordan TO, Leen $\mathrm{F}$, Keane $\mathrm{C}$, O'Moraine $\mathrm{CO}$. A prospective study of $\mathrm{H}$ pylori eradication in duodenal ulcer. Gastroenterology 1990;989:A 104.

53 Lambert JR, Borromeo M, Korman MG, Hansky J, Eaves ER. Effect of colloidal bismuth (DeNol) on healing and relapse of duodenal ulcers - role of Campylobacter pyloridis. Gastroenterologv 1987;92:1489.

54 Borody TJ, Cole P, Noonan S, et al. Recurrence of duodenal ulcer and Campylobacter pylor infection after eradication. Med $\mathcal{F}$ A ust 1989;151:431-5.

55 Glupczynski Y, Bourdeaux L, Verhas M, et al. Short-term double or triple oral drug treatment of Helicobacter pylori $(\mathrm{Hp})$ in Central Africa. (iastroenterologv 1990;98:A48.

56 Glupczynski Y, Buretta A, De Koster E, et al. Metronidazole resistance in Helicobacter pylori. Lancet 1990;335:976-7.

57 Glupczynski Y. In vitro susceptibility of Helicobacter pylori to antibiotics and bismuth salts and the importance of acquired resistance to antibiotics in treatment failures of $\mathrm{H}$ pylori infection. In Malfertheiner P, Ditschuneit H, eds. Helicobacter pylori, gastritis and peptic ulcer. Berlin and Heidelberg: Springer-Verlag, 1990:49-58.

\title{
HIV infection in children
}

\section{Millions will suffer}

By the end of next year, the World Health Organisation predicts that, world wide, over one million children will be infected with HIV, half of whom will have AIDS. ${ }^{\prime}$ This could increase infant and child mortality by as much as one third, making AIDS a major cause of death among children by the end of the century. Next week a conference will be devoted to the topic, organised jointly by the National Children's Bureau and the National AIDS Trust. Speakers will be urging closer cooperation between the statutory and voluntary sectors in caring for children with HIV infection. How much is known medically about this group?

The first reports of paediatric AIDS concentrated on terminally ill children who had been infected with HIV by their mothers ("vertical transmission"). ${ }^{2-4}$ Now the full range and natural course of HIV disease in children are emerging. ${ }^{56}$ Early diagnosis of HIV infection is essential because children may develop symptoms suddenly and have a high mortality. The mean incubation period for children infected with HIV is $4 \cdot 7$ years, but for those under 5 years old this is reduced to $2 \cdot 3$ years. The opportunity for effective intervention is therefore small.

Of those infants who acquire HIV infection from their mothers, one in four will develop AIDS in the first year of life; four fifths will have developed AIDS by the end of their fourth year. ${ }^{78}$ The European collaborative study reported recently that an estimated $83 \%$ of infected children show laboratory or clinical evidence of HIV infection by 6 months of age." Twenty six per cent had progressed to AIDS by 12 months, and the mortality from HIV related disease was $17 \%$. Subsequently, the disease progressed more slowly, with most children remaining stable during the second year of life. ${ }^{9}$
How may HIV infection be diagnosed in young children, in whom maternal antibodies may persist for up to 18 months? Tests that document infection, such as HIV antigen tests or culture, are not routinely available and may yield false negative results. $^{10}$ Hypergammaglobulinaemia has been suggested as an early and sensitive indicator of HIV infection, ${ }^{11}$ and without more definitive tests could be used as a surrogate test for HIV infection in children in whom chronic infections have been excluded.

With recent advances in managing adults infected with HIV, paediatricians will want to know which children might benefit from treatment. Factors correlating with or contributing to progression of disease have been evaluated in several cohorts. Two studies found that persistent antigenaemia with loss of core antibody was associated with poor outcome in children. ${ }^{12} 13$ Though measures of viral activity (core antigen levels) had little predictive power, tests of immune activation (serum neopterin and $\beta_{2}$ microglobulin concentrations) and immune deficits (absolute numbers of CD4+ $\mathrm{T}$ cells) were shown to predict accurately the progression to AIDS in infants born to mothers infected with HIV (C Courpotin et al, C Tuset et al, VIth international conference on AIDS, San Francisco, 1990). There is, however, a need to establish the normal range of serum concentrations of neopterin and $\beta_{2}$ microglobulin in children.

Although treatment with zidovudine prolongs survival in adults with low $\mathrm{CD} 4+$ counts $^{14}$ no placebo controlled trials have been done in children. Though most paediatricians would give zidovudine to children with AIDS, the optimal dosage, route, and frequency of delivery have not been determined. Reports of early phase I trials in children 
recommended treatment with high doses of zidovudine,,${ }^{15} \mathrm{a}$ practice that must now be questioned given that in adults low doses may be adequate. Multicentre trials are urgently needed to evaluate the safety and efficacy of zidovudine in children with early HIV disease.

On 31 December 1990, 32 countries reported a total of 2120 cases of AIDS in children under 13 years of age, half of whom were Romanian children with iatrogenically acquired disease. The outbreaks of nosocomial HIV infection in Romania and the Soviet Union highlight the continued need for screening of blood donors and for adequate sterilisation of medical equipment. Much has been learnt about vertically transmitted HIV disease, and large cohorts of children with horizontal transmission of HIV now need studying.

So far little attention has been paid to the problem of HIV infection and adolescents. A more complete understanding of the current epidemiology and natural course of HIV disease in this population is urgently required, followed by attempts to ascertain how best to care for infected adolescents. Only then can services be planned for those children now infected who may reach adolescence.

Although the longer term outlook remains unknown, HIV infection appears compatible with prolonged survival, with or without medical intervention. With this will come clinical, psychological, and social problems-for example, are staff and parents prepared to integrate children and adolescents infected with HIV into mainstream schools? And what are the financial implications of caring for "AIDS orphans"-young people who are not themselves infected with HIV but have lost one or both parents from AIDS? The World Health Organisation estimates that in the 1990s more than a million uninfected children will be orphaned throughout the world as their infected parents die of AIDS. ${ }^{17}$

Consultant Paediatrician,

City Hospital,

Edinburgh EH10 5SB

1 Chin J, Sankaran G, Mann JM. Mother to infant transmission of HIV: an increasing global problem. In: Kessel E, Awan AK, eds. Maternal and child care in developing countries. Thun, Switzerland: Ou Publishers, 1989

2 Oleske J, Minnefor A, Cooper $\mathrm{R} \mathrm{Jr}$, et al. Immune deficiency syndrome in children. $f A M A$ 1983:249:2345-9.

3 Rubinstein A, Sicklick M, Gupta A, et al. Acquired immunodeficiency with reversed ratios in infants born to promiscuous and drug-addicted mothers. FAMA 1983;249:2350-6.

4 Scott GB, Buck BE, Leterman JG, Bloom FL, Parks WP. Acquired immunodeficiency syndrom in infections. N Engl f Med 1984;310:76-81.

5 Scott (GB. Hutto C, Makuch RW, et al. Survival in children with perinatally acquired human immunodeficiency virus twpe I infection. $N$ Engl f Med 1989:321:1791-6.

6 Krasinski K, Borkowsky W, Holzman RS. Prognosis of human immunodeficiency virus infection in children and adolescents. Pediatr Infect Dis $\mathcal{F}$ 1989;8:216-20.

7 World Health Organisation Collaborating Centre on AIDS. AIDS surveillance in Europe Hôpital National de Sainte-Maurice, France: WHO, 1990. (Quarterly report No 28.)

8 Global surveillance and forecasting of AIDS. Bull World Health ()rgan 1989;67:1-7.

9 European Collaborative Study. Children born to women with HIV-I infection: natural history and risk of transmission. Lancet 1991:337:253-60.

10 European Collaborative Study. Mother-to-child transmission of HIV infection. Lancet 1988;ii: $1039-42$

11 Mok JYQ, Hague RA, Yap PL, et al. Vertical transmission of HIV: a prospective study. Arch Dis Child 1989;64:1140-5.

12 Epstein LG, Boucher CAB, Morrison SH, et al. Persistent human immunodeficiency virus type antigenemia in children correlates with disease progression. Pediatrics 1988;82:919-24.

13 Borkowsky W, Krasinski K, Paul D, et al. Human immunodeficiency virus type 1 antigenemia in children. J Pediatr 1989;114:940-5

14 Volberding PA, Lagakos SW, Koch MA, et al. Zidovudine in asymptomatic human immunode ficiency virus infection: a controlled trial in persons with fewer than $500 \mathrm{CD}+$ positive cells per cubic millimeter. N Engl f Med 1990;322:941-9.

15 Blanche S, Caniglia M. Fischer A, et al. Zidorudine therapy in children with acquired immunodeficiency syndrome. Am f Med 1988;85:203-7.

16 Pizzo PA, Eddy J, Falloon J, et al. Effect of continuous intravenous infusion of zidovudine in children with symptomatic HIV infection. N Engl f Med 1988;319:799-896.

17 Chin J. Current and future dimensions of the HIV/AIDS pandemic in women and children. Lancet 1990;447:221-4.

\section{Avoidable blindness}

\section{The numbers affected are still increasing}

About 30 million people in the world are blind ( 20 million more than in 1976), and a similar number are visually handicapped. Four fifths of this visual loss is avoidable. Last year's general assembly of the International Agency for the Prevention of Blindness produced several recommendations for action. Better use should be made of existing scarce resources. One in four of the world's ophthalmologists practise in the United States. In Africa there is an average of one ophthalmologist for every million people, but whereas $85 \%$ of Africa's people live in rural areas most of the ophthalmologists work in the large cities.

The needs of the developing world demand local solutions: techniques developed in Western hospitals - for example, yttrium, aluminium, and garnet lasers and intraocular lensesmay be irrelevant to eye work in rural areas of developing countries. In the Third World cataract tops the list of causes of bilateral blindness. Intracapsular cataract extraction and a pair of standard +10.00 glasses would cure half of the world's blind. One third of all patients attending eye clinics require a pair of spectacles - by setting up edging workshops to fit standard spherical lenses into cheap frames much needed spectacles could be provided for less than $\$ 5$. The world's poor are not well served by expensive imported eye medications, often unnecessary and harmful mixtures (steroids and antibiotics), promoted by seductive, glossy advertising. Eye drops manufactured in rural hospital pharmacies and put into recyclable bottles can cater for almost all common eye diseases at a fraction of the price. (The World Health Organisation recently published a paper on the local production of eye drops.)

How should the number of ophthalmologists serving the Third World be increased, and is a Western style training the best preparation for ophthalmologists working in underequipped rural locations? In Francophone Africa 22 countries with a population of 141 million) four centres providing postgraduate training in ophthalmology (Mali, Senegal, the Ivory Coast, and Zaire) produce only 10 specialists a year, which is hardly enough. An "average" ophthalmologist operates on 300 cataracts each year; half a million new cases of cataract develop annually in Africa, and a backlog exists of three million already blind. Perhaps other staff could be more easily trained - for example, general surgeons and dexterous ophthalmic nursing assistants have been successfully taught cataract surgery elsewhere. Realistic goals for manpower might be one ophthalmologist for every half million people and one cataract surgeon for every 250000 .

Experiences in several countries, most notably in Kenya, have shown the advantages of establishing a national committee for the prevention of blindness. Such a committee, under the auspices of the ministry of health, should include representation from all groups interested in eye care. A national survey into the incidence and prevalence of blindness 